\title{
An Assessment of "Zawarawa" Mass Marriage Programme, in Kano State, Nigeria
}

\author{
Rohana Yusof and Amina Lawal Mashi
}

\begin{abstract}
The study is to access the Kano state government social programme of reducing "Zawarawa" (menless womendivorcees, widows etc). The aims of the study is to evaluate the Zawarawa mass marriage programme, to identify factors responsible for high marriage breakdowns, to identify the effects of failed marriages on its victims as well as to recommend measures on how to reduce the incidences of marriage breakdowns in Kano State. Six officials of the Kano state Hisbah Board and 200 beneficiary women were served with questionnaires administered in English and Hausa Languages respectively. The results shows that mass marriage programme have been accepted by majority of the target population, that there is high success rate, and it has reduced level of poverty amongst the beneficiary women. The study recommends the expansion of the Mass Marriage Programme to other states of Nigeria and countries with similar social problems.
\end{abstract}

Index Terms-“Menless" women, "zawarawa", mass marriage project, spinsters.

\section{INTRODUCTION}

\section{A. Background of the Study}

There is no consensus about the definition of family by scholars [1]. However family has been defined as a 'group of two or more people related by birth, marriage or adoption and residing together, all such people are considered as members of the family [2]. The family is a central institution in all human societies, although it may take many different forms [3]. Similarly, family is still regarded as an important source of help and support and that family contacts are still maintained even though family members tends to leave further apart [4]. Marriage on the other hand has been defined as a union between man and a woman [5]. Marriage is an important social institution which promotes procreation, peace and a disciplined society free from all kinds of indecencies and vices. There are basically two types of marriage: Monogamy; this refers to a marriage of two individuals, while Polygamy, refers to a marriage where a man or a women have more than one spouse [6]. However, despite its religious and social significance marriage as an institution is today facing serious problems. One of these challenges is the alarming rate of "menless" women existing in our society who are divorced from their previous marriages or have ever not been married (Spinsters).

Manuscript received June 8, 2014; revised August 10, 2014.

Rohana Yusof is with the Northern Corridor Research Centre, Universiti Utara Malaysia, Sintok, Malaysia (e-mail: rohana@uum.edu.my).

Amina Lawal Mashi is with the Sociology Department, Umaru Musa Yaradua University, Katsina, Nigeria (e-mail: mashiamina@yahoo.com).
Divorce rate is also very high in sub-Saharan Africa. For example a BBC network African programme in collaboration with the Kano state, social re-orientation board, aired on March 2011, gave a gloomy picture about collapsed marriages or divorce rates in Kano state. "It was reported from the research conducted that $32 \%$ of marriages in Kano state survives only a period of three to six months; that many young women divorced of age 20-25years are said to have gone through three marriages at least; that there are more divorce than weddings in Kano every week; that it is not uncommon to come across young women who are less than 30years of age who have not been serially divorced etc". Furthermore, as at 2009 it was estimated that there were over one million zawarawa (i.e. menless women) in Kano state. This prompted Hajiya Altine Abdullahi, an executive Director, National association of divorcees/widows and orphans to threaten a protest march [7].

Various explanations about the increase in the rate of divorce have been provided: that the nuclear family suffers from an emotional overload, which increases the level of conflict between its members; that incompatibilities which were tolerated are now seen as intolerable; and the absence of love, once seen as unfortunate but bearable, is now taken as indicative of the retrievable breakdown of marriage; and that marriage is increasingly viewed as a 'relationship rather than a contract'. By getting married, people do not see themselves as entering, a binding, lifelong contract; rather they are hoping to establish a personally satisfying relationship: "love, personal commitment and intrinsic satisfaction are now seen as the cornerstones of marriage. The absence of these emotions and feelings is itself justification for ending the relationship" [8].

The effects of divorces on the family are many: The major one being its economic and material effects, as most affected women faces a lot of economic hardships, long-term effects on family roles and the feelings of family members (for example the affected family experienced diminished capacity for parenting after divorce and what sociologist called the "silver lining effect to the dark cloud of divorce) [9].

These are certainly very disturbing revelations, which should attract the attention of any serious minded government and other concerned members of the society. Various attempts towards tackling the menace of failed marriages in the state such as preaching by religious scholars, counselling by parents and efforts of match fixers (who roamed the streets of Kano with photo-graphs of "menless" women) seems to achieve very little success in reducing, let alone eliminate the menace of failed marriages. However, Kano state government under in collaboration with Hisbah Board seems to have found a solution to the problem through the comprehensive social programme tagged "zawarawa 
mass marriage programme". So far within a period of two years a total of 350 "menless" women have been married off and rehabilitated through financial and material support rendered to the couples to enable them engage in meaningful trade to support their families.

The Hisbah Board is one of the Kano state governments parastatal/agency established for the purpose of implementing some social Programs. Its mandates include: collaboration with the police to enhance security and crime prevention, moral counselling, traffic control, reconciliation services and the reduction of "zawarawa" ("menless women") through the arrangement of mass marriage program. The first phase of the mass marriage project took off on 15th May, 2012 with a total number of one hundred couples ("zawarawa"), while the second phase was conducted on 15th July 2012 with two hundred and fifty couples [10]. Plans have reached an advanced stage to marry off another set of 1111 couples.

The aims of the paper therefore is to appraise the Kano state government social programme, designed to reduce the number of "menless women" through the mass marriage project phase I and phase II so far conducted, and to make necessary recommendations on how to strengthen the project.

\section{THEORETICAL FRAMEWORK AND LITERATURE REVIEW}

"Marriage is a publicly recognized, more or less as permanent alliance between a man and a woman (i.e. a conjugal unit).In most societies the families of the partners have a role in establishing the relationship (often choosing the mate and at least manifesting their approval of the choice) and participate in the rite of passage which constitutes the formal marriage. Thus marriage legitimizes sexual access and the children as a result, are given an inscriptive position in the society as members of a particular lineage and family" [11].

Three sociological perspectives: Symbolic Interactionist, Structural Functionalist and Conflict, have provided useful insight into family roles and relationships. However, for the purpose of this study, emphasis would be given to Structural Functionalist perspective to provide explanations on the changing roles and relationships of the family in our societies today. It is hoped that this would help us in understanding the reasons for the various marriage breakdowns in our societies.

Functionalist Theorists, argues that the forms and functions of family is affected and shaped by the larger social environment in which the family operates. In other words as societies undergo such major changes particularly in Industrialization and Urbanization, the family must adopt to the effects of those changes in order to survive. Functionalist Theorists like Talcott Parsons and Williams Goode have noted the changing or loss of family functions. Thus "Modern families no longer perform certain functions that used to be within their domain, but they do play an increasingly vital part in early-childhood socialization, in the emotional lines of their members, and in preparing older children for adults roles in the economic institutions of industrial societies" [12].

All major Sociological Perspectives support the view that the family is a resilient institution; it adapts to changing economic conditions and changing values. The traditional family, according to Structural Functionalist has provided support to the couples and their children in a number of ways: sexual regulation, reproduction and replacement through given birth to children, socialization as the family serves as the main training ground for children, emotional support and protection from all kinds of frustrations and dangers, and economic support i.e. provision of shelter, food, education etc. However, the roles and functions of family in the new changing social order have been transferred to other institutions for instance, socialization has been transferred to schools, economic functions have gone to the factories, the traditional protection and care function have been partially taken over by the police etc. [13].

The major consequence of changes on family roles and functions is increase in single parenthood.

\section{Increase in Single Parenthood}

Single parenthood can come about through a number of different routes:

Divorce: is simply the dissolution or termination of marriage. It involves the cancellation of all legal duties and responsibilities of marriage. Divorce is unlike annulment which declares marriage null and void. The legal process of issues of alimony (spousal support), child custody, and child support. Several studies have shown that divorce rate is growing around the globe. It was reported that there was a doubling in the proportion of young people aged 25 to 44 , and men aged 45 to 64 , living alone between 1986/7 and 2005/6; that the proportion of people in their twenties who lived alone increased from 3 percent in 1973 to 9 percent in 1996; and that number single women increased from $28 \%$ in 1960 to $67 \%$ in 1994 [14].

In recent times, particularly in Kano state divorce has reached an alarming rate. As at 2009 it was estimated that there were over one million zawarawa (i.e. menless women) in Kano state which prompted Hajiya Altine Abdullahi, an executive Director, National association of divorcees/widows and orphans to threaten a protest march.

Increase in poverty, particularly amongst "zawarawa" the ("menless women"). This is particularly more pronounced in less Developed Nations of Africa and Asia, where majority of women are not educated and not gainfully employed, thus making them entirely dependent on their husbands. "Women suffer an average decline of about $30 \%$ percent in their income first year after separation while men experience a $10 \%$ increase" [15].

Psychological problems: Beyond materials effects of divorce, there are the longer term effects on the family roles and feeling of family members. "Many divorced adults continue to feel angry, humiliated and rejected, while the children of divorced parents tend to exhibit a variety of psychological problems. Moreover, both men and women have a diminished capacity for parenting after divorce. They spend less time with their children, provide less discipline and are less sensitive to their needs. Even a decade after the divorce, the parents may be chronically disorganized and unable to meet the difficulties of parenting. Instead, they come to depend on their children to help them cope with the demands of their own lives, thereby producing an "over-burden children"- one who, in addition to handling the 
normal stress of childhood, also must help his or her parent ward off depression [16].

Individuals whose parents divorced during their childhood have a higher probability of teen marriage, divorce, peer problems, delinquency, truancy and depression [17].

\section{Methodology}

The research was conducted at Hisbah Board Headquarters Kano. The research targeted 200 women randomly selected out of the 350 "men less" women married off as at July 15th, 2012. Six officials of the Hisbah Board in charge of the "zawarawa" mass marriage programme were selected for the study. In carrying out the research one set of questionnaire and an in-depth interview were used. The questionnaire for the beneficiary women was administered by the researchers in Hausa Language (as most of them were not literate), while the in-depth interview with the Hisbah board officials was conducted in English Language. The questionnaires were analyzed and the results presented in a table with the women responses coming first, followed by the interview conducted with the officials of the board.

\section{DATA ANALYSIS WOMEN RESPONSES}

TABLE I: REASON FOR SEPARATION FROM PREVIOUS MARRIAGE

\begin{tabular}{lcc}
\hline Response & Frequency & Percentage (\%) \\
\hline Death of former & 68 & 34 \\
husband(widows) & & \\
Divorce & 115 & 57.5 \\
Spinster & 17 & 8.5 \\
Total & 200 & 100 \\
\hline
\end{tabular}

Table I above, indicates that $(57.5 \%)$ of the respondents cited divorce as the main cause of marriage break ups. Divorce as a results of so many reasons (such as abuse of religious and Islamic tenets governing marriage and divorce, lack of patience by the couples, poverty etc.). These factors constitute the major reasons for marriage break ups in our society today. $34 \%$ of the respondents lost their marriage unions due to death of their husbands (widow ship). Death is a natural end and therefore does not constitute a social problem. However, there is the need to evolve a program like the mass marriage project to carter for their (i.e. widows) interest. It is however interested to note that $8.5 \%$ of the respondents are spinsters i.e. those girls who for whatever reason could not find a suitor on their own; but had to enlist the support of Hisbah board to achieve their goals. It is now a global phenomenon, for girls/women to spend a lot of year searching for an appropriate partner/husband. So many factors account for this ugly situation: women population relative to that of men, unreasonable/tall ambition of the women to marry readymade husbands who are rich, the economic downturn and unemployment associated with men who cause delayed marriages and the fact that men nowadays are not interested in marrying more than one wife. This is causing African Societies to experience similar divorce problems, Europe and America had been experiencing for many decades. The responses also collaborated with the views of the Hisbah board officials where they cited divorce, death of husbands and spinsters as the major causes of "menless" women in Kano state.

TABLE II: HARDSHIPS "MENLESS" WOMEN EXPERIENCED

\begin{tabular}{lcc}
\hline Responses & Frequency & Percentage \\
\hline Lack of Security and respect & 40 & 20 \\
Lack of care and maintenance & 83 & 41.5 \\
Separation from children & 37 & 18.5 \\
Difficult in raising up children as & 40 & 20 \\
single parent & & \\
Total & 200 & 100 \\
\hline
\end{tabular}

Table II above, indicated that majority of the respondents $(41.5 \%)$ said they experience lack of care and maintenance and $20 \%$ of the respondent reported lack of security and respect from the society. While $(18.5 \%)$ reports experiencing difficulty due to separation from their children. Similarly $(20 \%)$ reported difficulty in rising up their children as single parents.

TABLE III: FACTOR LEADING TO BREAKDOWNS OF MARRIAGES

\begin{tabular}{lcc}
\hline Responses & Frequency & Percentage \\
\hline Lack of Islamic knowledge & 71 & 35.5 \\
governing rules of Marriage & 32 & 16 \\
Lack of Patience & 11 & 5.5 \\
Misunderstanding/communication & & \\
gap between couples & 86 & 43 \\
Abandonment of marriage & & 100 \\
responsibilities & 200 & \\
Total & & \\
\hline
\end{tabular}

Table III above, shows various reasons accounts for marriage breakdowns: (43\%) of the respondents said the abandonment of marriage responsibilities by the husbands (i.e. lack of feeding, shelter, education of children etc.) as one of the major factor causing marriage breakdowns. While $(35.5 \%)$ of the respondents stated ignorance or lack of respect to religious teachings governing marriage, thus making the men not take marriage as an important institution in the society. (16\%) of the respondents however, reported lack of patience especially during periods of misunderstanding and quarrels which are unavoidable in marriage relationships. Similarly $(5.5 \%)$ of the respondents stated lack of understanding and proper communication between the spouse which often leads to quarrels.

TABLE IV: MEASURES TO REDUCE MARRIAGE BREAK-UPS

\begin{tabular}{lcc}
\hline Responses & Frequency & Percentage \\
\hline $\begin{array}{l}\text { Inculcation to Religious teachings by } \\
\text { parents/spouses }\end{array}$ & 35 & 17.5 \\
$\begin{array}{l}\text { Marriage not based on materialism, } \\
\text { but on love, understanding and }\end{array}$ & 39 & 19.5 \\
$\begin{array}{l}\text { respect. } \\
\text { Husbands to discharge marriage } \\
\text { responsibilities adequately } \\
\begin{array}{l}\text { Patience and adequate } \\
\text { communication between spouses }\end{array}\end{array}$ & 92 & 46 \\
Total & 34 & 17 \\
\hline
\end{tabular}

From Table IV above, (46\%) of the respondents said husband should take their marriage responsibilities seriously 
(i.e. of providing feeding, clothing, education, shelter, protection etc.) seriously, and (19.5\%) said marriage should not be based on materialism, but rather it should be based on love, respect and understanding as marriage has its ups and downs. However $(17.5 \%)$ of the respondents said married couples should learn and respect their religious teachings on marriage and divorce and be patient. Similarly (17\%) of the respondents insisted that couples should communicate well amongst themselves in order to clear all grey areas in their relationships, as well as be patient with each other when there are mistakes or understandings.

TABLE V: Ways to StRengthen the Mass MarRiage PRoject

\begin{tabular}{lcc}
\hline Responses & Frequency & percentage \\
\hline $\begin{array}{l}\text { More support from nongovernmental } \\
\text { organisations/wealthy Individuals }\end{array}$ & 64 & 32 \\
$\begin{array}{l}\text { Enactment of appropriate legislation to } \\
\text { safeguard marriages }\end{array}$ & 62 & 31 \\
$\begin{array}{l}\text { Expansion of mass marriage to local } \\
\text { government headquarters }\end{array}$ & 54 & 27 \\
$\begin{array}{l}\text { To Provide a forum to attract educated } \\
\text { and working class "menless" women }\end{array}$ & 20 & 10 \\
Total & 200 & 100 \\
\hline
\end{tabular}

Table $\mathrm{V}$ above, indicates that $(32 \%)$ of the respondents urged for more support of the mass marriage program from private organizations and wealthy individuals to compliment the efforts of the government. (31\%) of the respondents called for enactment of an appropriate Law by the Kano state government to guarantee the continuation of the program after the tenure of the present administration in view of its importance to the society. Furthermore $(27 \%)$ of the respondents advised that the mass marriage programme should be decentralized to the 44 local governments of the states in order to accommodate more women and ease the hardship of travelling to Hisbah board headquarters for those coming to benefit from the program. However, (10\%) of the respondents, urged the Hisbah board to create a forum to encourage highly educated and well placed" menless" women in the state to benefit from the programme, as most of them feel shy to go to the Hisbah board to register. A website and an email address should be opened where such women can register.

\section{A. In-depth Interview with Hisbah Board Officials}

\section{1) Reasons for the Mass marriage}

All the respondents said the Kano state government was disturbed by the increasing number of "Menless" women (i.e. divorcees, widows and spinsters) roaming the streets, thus causing a lot of social problems such as prostitution and crime. Consequently, the Kano state government in collaboration with Kano state Hisbah came up with a public policy tagged "zawarawa" mass marriage to tackle the menace. However, they said:

"The specific aim of the programme is to reduce the number of "menless" women, reduce sexual abuse, and prostitution to inculcate disciplines and patience amongst married couples, to assist married with financial and material assistance to reduce idleness and poverty".

2) Factors responsible for high rate of "menless" women

The respondents gave various reasons for the increasing "menless" women in the state. They said:

"In fact it is a combination of so many factors that over time culminated into the growing number of "menless" women in the state. These factors include- high divorce rate due to total disregard to adherence of religious teachings governing marriage and divorce, emphasis on materialism rather than love while marrying, lack of patience and understanding by couples especially during period of crisis and the biggest being the crippling poverty amongst couples, which move often than not made some husbands to abandon their basic marital duties with regards to feeding, clothing, medical, "death of husband (widows), and spinsters particularly women who could not find suitable husbands/girls to marry".

\section{3) Channels and criteria used in linking suitors}

The respondents said: The board has introduced means and procedures which all men and women interested in getting married would have to follow to actualize their goals.

"According to them these procedures includes: a visit to the Hisbah board to indicate interest and fill forms giving all personal data including photographs, interview and medical /screening to ascertain the health condition of those wishing to be joined in marriage union. The future brides are then encouraged to interact and know themselves fully in order to foster understanding and love before the marriage fatiha and wedding is done".

\section{4) Safeguards adopted by the Hisbah Board to protect marriages from failing.}

The officials indicated that "a lot of safeguards have been incorporated to ensure that failed marriage is reduced to the minimum. These safeguards started from i.e. initial stage of registering and filling forms at the board where all personal details and health records are disclosed in addition to photographs. So the suitors would a first of all have to glance at the pictures, the background of the person including ages, level of education, employment or trade/craft, health records, records of his/her previous marriages number etc. It is after all these are disclosed to the suitors before they give an opportunity to interact. So these in our opinion forms the first safeguard to the marriage, as the partners were joined based on marital facts about one another, i.e. no deception. Other safeguards include- the filling of marriage contract between the board and new married couples, issuance of marriage certificate, continuous invitations/counselling to the homes of the couples by the board to ensure that problems are solved before they escalate, this is all in addition to financial and materials benefits given to the women to engage in some productive/business activities".

\section{5) Number of women married out and problems encountered by the board}

The respondents said:

"Under the phase I and II of the mass marriage program, a total number 350 couples have been joined to marriage, adding that a plan has reached an advance stage to marry off one thousand one hundred and eleven (1111) suitors by the board".

In respect of problems encountered by the board, the officials reported that:

"Even though the state government is doing its best in 
funding the project, which has so far released 76million naira for the project, the board has to appeal to wealthy individuals in the society to give a helping hand as the government cannot shoulder all the responsibilities alone. So the problem of finding the project is still one of the problems facing the board. Some other minor problems include insincerity by a very small percentage of the public who either "impersonate" or are just interested in collecting the token material and financial assistance rendered to the couples by the board." Furthermore, the officials said "wealthy individuals have made wholesome contributions of materials and money running into millions of Naira".

\section{B. Measures to Strengthen the Project}

The officials believe this is an important social program which should be encouraged not only the government, by wealthy individuals and united nations. This is because marriage breakdowns/failures are now a universal phenomenon which directly threatens our society in many ways such as increase in rampant prostitutions, existence of delinquent and unproductive youths that contributes in no small measures to increase in crime rate. Therefore, all hands must be on deck to tame this monster of family breakdowns. The respondents specially said "there is the urgent need to have a holistic approach by all stakeholders, especially religious leaders, parents and schools in solving this problem. This can be achieved through the enactment of legislation to ensure continuity of the program after this administration of Governor Rabiu Musa Kwankwaso, more support from private individuals and organizations.

\section{Discussion OF FINDINGS}

Major findings of this research would be discussed in line with the objectives of the study which are: To evaluate the mass marriage programme, Identify factors responsible for mass marriage breakdowns, to identify the effects of failed marriages on its victims, families and society and to recommend appropriate measures on how to reduce the incidence of marriage breakdowns in the states; and the relevant conceptual frame work.

The data collected and analyzed from the research seems to justify the objectives of the study. These are analyzed as follows:

The study highlighted the importance of the mass Marriage programme due to the existence of an alarming number of "Menless" women in Kano state, as a result of frequent Marriage break ups due to a number of factors. In fact this lead to the threat of one million protest match by divorcees in Kano state in 2009 to voice their anger and frustration on men and the government as they could not find husbands, some of them for many years after their divorce or death of their husbands. The mass Marriage programme initiated and executed by the Governor Rabiu Musa Kwankwaso government is indeed a stitch in time, which has greatly given hope to those frustrated "menless" women in the society. The programme has also achieved other objectives such as reduction in prostitution, youth crime, and truancy and depression amongst the target population and their families.

As part of the objectives of the study, the findings identified so many factors that precipitate marriage breaks down thus leading to an alarming rate of "menless" ("zawarawa") in the society. The factors include high rates of divorce, window-ship and so many spinsters. The consequences of having many "menless" women in any society are many and they include increase in prostitution, increase in crimes and delinquency particularly amongst the affected women and their children. For example divorce accounts for $(57.5 \%)$ amongst the factors that causes marriage break ups in Kano state. The Kano state mass Marriage programme is really in line with the views of structural functionalist theory which emphases the importance of family in the stabilization of family and society which is done through a number of means; sexual regulation which is done by every society in accordance with its own values, often through marriage; reproduction and replacement to guarantee the existence and continuity of society as children are made to replace members who die as well as to keep family lineage, inheritance clear; provide emotional support and protection, as family provides source of love, and belonging, security, protection and safety from harm, economic support etc. In fact according to a BBC documentary tagged "collapsed marriages" in Kano, "that $32 \%$ of all marriages in Kano survive only a period of 3-6 months, and that there are more divorce than weddings in Kano every week". Furthermore, Widow-ship, this is another factor that leads to separation, thus adding to the growing number of "menless" women in the state by (34\%). Spinsters, this are young girls who have never been married although they are interested in getting married but could not do so due to some reasons. These reasons varies from lack of finances by their parents to carry out the marriage rituals, lack of suitable suitors and their high economic expectations i.e. getting readymade men who had made it in life economically and socially, this perhaps proves the argument of Rational Choice or Exchange Theory which evaluates the costs and rewards of engaging in an interaction to try to find the "best deal". This group of people according to the research finding constitutes $(8.5 \%)$. This findings seems to support the conflict theory which argues that conflict in families is as a results of struggle for power and control in the family unit and in the society at large. Family was seen as the chief source of female oppression and that until basic resources were allocated within the family women would continue to be oppressed.

The study identified various effects "menless" women experienced from their husbands. $41.2 \%$ of the respondents cited increase in poverty due to lack of care and maintenance, while $20 \%$ reported lack of security and respect from the society.

Sociologists have reported various consequences /hardships associated with divorce. "First there are the emotional aspects of divorce, since divorce is seen as a failure, rejection and even punishment. More often than not divorce involves splitting with family and many close friends There are also costs for children, as children lives are turned upside down; thus" Many children move to new houses/Locations, leave one parent and friends and make adjustments to new schools. Divorce lowers the well-being of children in the short term, affecting school achievement, 
peer relationships and behavior [18].

\section{CONCLUSION}

Family break-ups constitute one of the serious problems facing marriage as an institution, all over the world today. In view of the important role family plays in the society, there is the urgent need for governments and other stakeholders to evolve ways of saving families from frequent marriage break ups. One of such initiatives was the introduction of mass marriage project by the Kano state government in collaboration with Kano state Hisbah Board. The program was designed to provide a forum where women and men can interact and eventually get married. So far the project has recorded a lot of success stories i.e. it has reduce the number of men less women in the state; as well as achieved poverty reduction amongst the beneficiaries. Other states in the Northern Nigeria and Countries where high incidence of divorce/ separations/ and Spinsters are common, need to have a critical look at the Kano state mass marriage project as a panacea in solving similar problems in their States/Countries.

\section{RECOMMENDATIONS}

1) Expansion/decentralization of the program to Local Government Area of the state.

2) "Menless" women who desire a separate forum to be establish to give chance to "menless" educated women to find suitors.

3) Parents to take marriage of their children too seriously especially in selecting a partner for them.

4) Women to be encouraged to acquire education and skills to make them economically productive, thus reducing their dependence on their husbands and parents.

5) Since the problems of "menless" women cut across most of the northern states and indeed the country as a whole, the Kano state governors to implement similar social program in their states. Similarly, the Federal Government under its ministry of women affairs should introduce a similar program for whole the country. This is because family as an institution must to be safeguarded and protected by all means and sundry in order to have a decent and productive society.

6) The prospective couples should be encouraged to uphold the importance and advantages of medical test before marriage.

7) Our religious / traditional teachings about marriage, how marriage should be conducted, conflict resolution between spouses and divorce should be respected by all parents. This would ensure that marriages are done base on love and not materialism, beauty or lust.

8) Husband and wife should learn to forgive each other and approached each other more gently and lovingly when reconciliation was required, as a forgiving heart always brings healing to wounded relationships

\section{REFERENCES}

[1] Degenova and Rice, Intimate relationships, Marriages and Families, $5^{\text {th }}$ ed., New York- McGraw Hill, 2002.

[2] U. S. Consensus Bureau. (2005). Housing Vacancies and Housing Ownership Annual Statistics. [Online]. Available: http://www.census.gov/hhes/www/housing/hvs/annual/105/ann05def. html

[3] W. Kornblum, Sociology in Changing World, Wadsworth Eighth Edition, Belmont CA: Wadsworth Publisher, 2005.

[4] F. McGlone, A. Park, and C. Roberts, "Relative values: kinship and friendship," in British Social Attitudes: the $13^{\text {th }}$ Report, R. Jowell et al. eds., Darthmouth, Aldershot, 1996.

[5] H. Jeanne et al., Our Social World Introduction to Sociology, Saga Publication Ltd UK, 2007.

[6] B. David, "Evolution, males, and violence," The Chronicle Review, May 24, 2002

[7] BBC Network African Programme. (2011). [Online]. Available: http://www.google.com.ng/gwt/x?gl=NG\&hl=en

[8] Haralambos and Holborn, Sociology: Themes and Perspectives, $5^{\text {th }}$ ed., New York; McGraw Hill, 2000.

[9] H. Jeanne and A. K. Robert, Our Social World Introduction to Sociology, Saga Publication Ltd UK, 2007.

[10] K. Hisbah. (May 2013). Kano state Hisbah Board. A New Dawn. [Online]. 1(1). Available: http://www.kanohisbah.gov.ng

[11] M. Peil, Consensus and Conflict in African Societies: an Introduction to Sociology, East African Publishing House, 1968.

[12] W. Kornblum, Sociology in Changing World, Wadsworth Eighth Edition, Belmont CA: Wadsworth Publisher, 2008.

[13] Haralambos and Holborn, Sociology: Themes and Perspectives, $6^{\text {th }}$ ed., New York; McGraw Hill, 2004.

[14] P. A. McManus, T. A. D. Preter, Haralambus, and Holborn, Sociology: Themes and Perspectives, New York McGraw Hill, 2001.

[15] J. Wallerstain and S. Blakeslees, Second Chance: Men, Woman and Children a Decade, After Divorce, New York: Ticknor \& fields, 1989.

[16] A. J. Cherlin, Marriage, Divorce, Remarriage, Cambridge MA: Harvard University Press, 1981.

[17] P. R. Amato and J. M. Sobolewski, "The effects of divorce and marital discord on adult children's psychological well-being," American Sociological Review, vol. 66, no. 900-921, 2001.

[18] P. A. McManus and T. A. DiPreter, Haralambus and Holborn; Sociology: Themes and Perspectives, New York McGraw Hill, 2001.

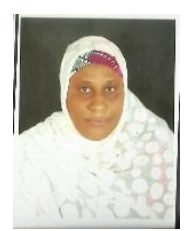

Amina Lawal Mashi possesses Msc Sociology (2011) Bayero University Kano Nigeria, Master of Business Administration (2004) Bayero University Kano Nigeria. She has 14 years working experience since graduate from the University of Abuja Nigeria 1994. She worked with former Bank of the North Kano Nigeria which later merged and become unity bank Plc Nigeria for over 12 years, where she held various positions including Finance officer and Risks and credit officer of the Bank. She joined Umar Musa Yaradua University Katsina Nigeria in September 2012 as Assistant Lecturer, sociology department. She has published twenty papers in different journals on contemporary issues in areas of health, gender studies and social policy.

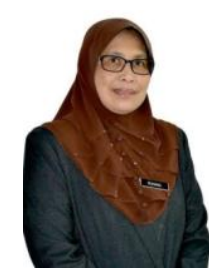

Rohana Yusof obtained her first degree in Sociology and Anthropology at Universiti Kebangsaan Malaysia, Malaysia in 1983. Then, further her studies at University of Lancaster, United Kingdom in Master of Arts Contemporary Sociology in 1987 and obtained her Doctorate in Gender and Development Management in 2006. She became a lecturer at Sekolah Pengajian Asasi, Universiti Utara Malaysia in 1988. Despite of working as a lecturer, she is the Director of Northern Corridor Research Centre (NCRC), Universiti Utara Malaysia from year 2010. Dr. Rohana Yusof had published more than one hundred publications and involved in sixty four research projects as a project leader and co-researcher. Her main current research areas are socio-politics, gender studies and rural development and poverty. 